\title{
Is elevating Sir John A. Macdonald really worth it? Hitting the reset button on Canada's founding narrative in the classroom
}

\author{
Adam Gaudry \\ Department of Political Science \\ Faculty of Arts / Faculty of Native Studies \\ University of Alberta \\ adam.gaudry@ualberta.ca
}

In August 2017, the Elementary Teacher's Federation of Ontario (ETFO) passed a motion calling on the province to remove the name of Canada's first prime minister, Sir John A. Macdonald, from all of Ontario's schools (Nasser, 2017). Building on years of criticism of Macdonald by Indigenous intellectuals, the ETFO's motion is only the latest move to displace Macdonald in the Canadian nationalist mythos. To most Indigenous people (and to an ever-increasing number of Canadians) Macdonald is remembered chiefly for his horrors: Indian residential schools (Milloy, 1999), the starvation policy on the plains (Daschuk, 2013), the wholesale refusal to honour treaty relationships (Asch, 2014; Venne, 1997), a violent military confrontation with three Indigenous communities in 1885 (Adams, 1989; Stonechild \& Waiser, 1997), and his longstanding goal of politically marginalizing (if not physically exterminating) Indigenous nations (Stanley, 2015).

Yet, while calling for the displacement of Macdonald, progressive voices have never actually sought to downplay Macdonald's role in the formation of Canada. Instead, these voices seek to communicate Macdonald's legacy in a more honest way by naming Canada's first prime minister as the architect of many of Canada's imperialistic structures, structures which are integral to Canada's existence. Without the theft of Indigenous lands, without ignoring nation-to-nation treaty relations, and without the longstanding and often violent denial of on-going Indigenous self-determination, Canada would not be what it is today (Carleton, 2017). The goal has never been to change the past, but to change the way people learn about it, and more fundamentally to end Canada's multifaceted and ongoing colonization of Indigenous peoples. The point of the ETFO motion - and other demands like it - is not to displace Macdonald from his founding role, but to use him as an entry point for Canadians to understand the country's legacy of imperial violence that has generated this unjust relationship between Canada and Indigenous nations, a relationship we are now all saddled with today.

Transformative education is certainly one important way to achieve this end. Dakota scholar Waziyatawin (2008) advocates for a process of intellectual honesty she calls "truthtelling" education, ensuring learners understand that "what has passed for the truth may not be truthful after all" (p. 71). It is "the transformative potential of education" that posits "once people understand the truth, they will be compelled to act more justly" (Waziyatawin, 2008, p. 71).

In my experience, truth-telling has two components, the first of which involves learning new information - or in particular, the other side of the story. The second and more challenging part of this truth-telling education is unlearning what passes as the common- 
sense history of Indigenous-Canadian relations. Simply adding in new information, or implying that "other voices need to be heard" without accounting for the historical and contemporary denial of Indigenous humanity is insufficient. Without a degree of unlearning, hearing "the other side" Macdonald's story does little to transform the ways in which Canada continues to function as an imperial power. Therefore, learning about Macdonald and his impact on Indigenous nations also requires unlearning much of the mythology about him. In order to do so, it's probably necessary for students to also understand whose interests are served if the celebration of Confederation through Macdonald is deemed to be more important than over narratives, which tell the more honest story of Canada's erasure and political marginalization of Indigenous peoples.

To be truly transformative, to have impacts beyond the classroom, Macdonald and Canada's myriad colonial policies cannot simply be "another perspective," but rather must become a central part of how Canadians understand Canada's history-and present. But teaching and learning about Macdonald can also be effective for affecting this kind of change. There are already substantial resources on Macdonald's legacy, a number of which are cited in this article, that allow for a transformative historical analysis of the legislation, law, and policy he brought into being. To move forward we must reject Macdonald and his horrific legacy, but this does not mean ignoring him either. His legacy, in order to be undone, must be extensively studied, taught, and then dismantled in practice. Doing this task as an intellectual exercise must be a mere prelude to doing it for real.

The first question we should ask is whether or not Macdonald is actually worth holding onto at all. Is there something about Macdonald's legacy that establishes a suitable morality for Canadians? Does this Macdonald-centred Canadian identity actually inspire anyone to be a better person? Much of the Macdonald-as-Canadian-founder narrative is relatively young. Adele Perry (2017) notes that was not until the 1960s and 1970s that Canadians really began to commemorate Macdonald's as the founder of Canada. It was only during Canada's centennial years that a selfconscious movement made Macdonald "into a general symbol of nationhood, stripped of much of its messy, partisan, and often violent history" (Perry, 2017). In other words, Macdonald's status as the founding father of Canada is of rather recent vintage.

To continually celebrate Macdonald also presumes that Canadian desires for a "general symbol of nationhood" are more important than the integrity of Indigenous lands and lives, whose devaluation and dehumanization are also an integral part of Canadian nation-building. Many of Macdonald's key policies targeted Indigenous peoples in particular, and at other times he willfully ignored them in ways that also advanced Canadian interests over Indigenous ones. Macdonald built a railroad over Indigenous lands, and his government passed the notorious Indian Act into Canadian law which slowly and steadily limited autonomous decision-making by Indigenous political communities. The numbered treaties were negotiated under his watch, and he oversaw the spectacularly callous refusal to honour them as buffalo populations collapsed and people requested the agreed-to federal aid (Daschuck, 2013; Miller, 2009). Métis on the South Saskatchewan sent 84 petitions to Parliament in the 1880s criticizing land-surveying policies overseen by Macdonald's government. His persistent refusal to respond led to the declaration a provisional government, which in seeking to negotiate with Canada for the protection of their lands, ultimately fought Canadian troops dispatched by 
Macdonald from the East (Adams, 1989, p. 77). A key legacy of Macdonald's is Canada's longstanding refusal to respect Indigenous nations as nations - nations who control territory, who govern their people, who predate Canada and its claim to govern them.

Understanding, too, that Macdonald was opposed at every step of the way is an important and powerful reminder that, despite his attempts to undermine Indigenous power, Indigenous peoples continue to assert control over our own existence. On the prairies some of our most celebrated heroes are those who fought Macdonald's troops: Big Bear, Louis Riel, Poundmaker, and Gabriel Dumont, all of whom were active during Macdonald's reign in resisting Canadian encroachment on Indigenous land and jurisdiction.

But there were Canadians who also resisted Macdonald and his policies. These nonIndigenous people serve as important reminders that the Canada Macdonald built was not inevitable, nor was it desired by every Canadian. There have always been Canadians who aspire to more than the Canada presented to them by their government, and those Canadians are needed now as much as they ever have been.

One such example is Dr. Peter Bryce, publicly lauded by Indigenous child welfare advocate Cindy Blackstock. As the chief medical officer of the Department of Indian Affairs in 1907, Bryce studied the of out-of-control tuberculosis infections in Indian residential schools. When the government failed to take action, Bryce leaked this information to the Ottawa Citizen to pressure the government to act (CBC News, 2017). Even in an era of seemingly unquestionable Canadian colonialism, Canadians still aspired to build a more just world, even if their government was publically unwilling. We can look to them, rather than Macdonald, to build a better future.

As we enter into an era of truth-telling, there is a renewed call to, like Peter Bryce, act honourably in the face of grave injustice. It is vital to know Macdonald and what he stood for, and then to acknowledge that his example cannot be the basis for Canada moving forward - his legacy cannot be the basis of an honourable and just relationship between Canada and Indigenous nations. Educators have a central role to play in navigating this challenging terrain.

There is an expression that often gets used in Indigenous governance circles, "when the people lead, the leaders follow." Perhaps Canadians - and Canadian educators in particular - can find resonance with this idea, too. Even if the Canadian government has been reluctant to implement transformative policy, even if it is non-responsive to powerfully transformative educational aspirations, Canadians can nonetheless put truth-telling and its necessary unlearning into action without their political leaders, and thus build meaningful and collaborative partnerships with Indigenous nations. Until such a time that the Canadian government undertakes these responsibilities itself, Canadians themselves will have to lead their government. As the ETFO has already demonstrated, educators have an important leadership role to assume in this struggle, and a truth-telling education that amplifies Indigenous voices can be an important first step. 


\section{References}

Adams, H. (1989). Prison of grass: Canada from a Native point of view. Edmonton, Canada: Fifth House.

Asch, M. (2014). On being here to stay: Treaties and Aboriginal rights in Canada. Toronto, Canada: University of Toronto Press.

Carleton, S. (2017, July 9). John A. Macdonald was the real architect of residential schools. Toronto Star. Retrieved from https://www.thestar.com/opinion/commentary/2017/07/09/john-a-macdonald-was-thereal-architect-of-residential-schools.html

CBC News. (2017, June 2). Ottawa doctor who sounded alarm on residential schools remembered with exhibit," $C B C$ News. Retrieved from http://www.cbc.ca/news/canada/ottawa/peter-bryce-exhibit-ottawa-church-residentialschools-1.4142766

Daschuk, J. (2013). Clearing the plains: Disease, politics of starvation, and the loss of Aboriginal life, Regina, Canada: University of Regina Press.

Miller, J. R. (2009). Compact, contract, covenant: Aboriginal treaty making in Canada, Toronto, Canada: University of Toronto Press, 2009, page 153-171.

Milloy, J. (1999). A national crime: The Canadian government and the residential school system, 1879 to 1986. Winnipeg, Canada: University of Manitoba Press.

Nasser, S. (2017, August 23). He's considered Canada's founding father, but many Ontario teachers want his name stripped from public schools. CBC News Toronto. Retrieved from http://www.cbc.ca/news/canada/toronto/john-macdonald-school-1.4259643

Perry, A. (2017, September 9). Renaming monuments is closer look at history. Winnipeg Free Press. Retrieved from https://www.winnipegfreepress.com/opinion/analysis/renamingmonuments-is-closer-look-at-history-443377973.html

Stanley, T. J., (2015, January 7). John A. Macdonald's Aryan Canada: Aboriginal genocide and Chinese exclusion. Active History. Retrieved from http:/activehistory.ca/2015/01/john-amacdonalds-aryan-canada-aboriginal-genocide-and-chinese-exclusion/

Stonechild, B., \& Waiser, B. (1997). Loyal till death: Indians and the North-West Rebellion, Edmonton, Canada: Fifth House.

Venne, S. (1997). Understanding Treaty 6: An Indigenous perspective. In M. Asch (Ed.), Aboriginal and Treaty Rights in Canada (pp. 173-207). Vancouver, Canada. University of British Columbia Press.

Waziyatawin. (2008). What does justice look like? The struggle for liberation in Dakota homeland. St Paul, MN: Living Justice Press. 